\title{
Renovation of the Centennial Hall
}

\author{
Maciej Czarniecki ${ }^{1}$ and Daniel Czerek $^{2}$ \\ 1. Targpiast Sp. z o.o., Wroclaw 51-114, Poland \\ 2. Wrocławskie Przedsiębiorstwo Hala Ludowa Sp. z o.o., Wroclaw 51-618, Poland
}

\begin{abstract}
The Centennial Hall was designed as a monumental building entirely of reinforced concrete. Soon it became a model for modernist buildings of that era. During the years 2009-2011, the biggest renovation since its completion took place. All activities described in the following paper aimed to put the Centennial Hall into good repair and adjust it to the applicable requirements of modern public buildings. The primary aim is to preserve the authenticity of the original materials used in construction through the use of remedial technologies, thereby maintaining the historical integrity of the building.
\end{abstract}

Key words: Building renovation, Centennial Hall, monument.

\section{Introduction}

The Centennial Hall was built in 1911-1913 according to the design by Max Berg. The building is located in the central part of the old Exhibition Grounds, currently called the Centennial Hall Complex. The complex is situated in the immediate vicinity of Szczytnicki Park and the Zoological Gardens, in the north-east part of Wroclaw. The ribbed dome of the Centennial Hall was the biggest in the world at the time of the building's completion. It exceeded the size of the dome of Hagia Sofia and the Pantheon in Rome. The unprecedented span of the dome constituted a challenge for designers who had to use precursor construction solutions. Since its completion, the Centennial Hall has been a model for monumental modernist buildings and one of the most significant works of the 20th century architecture.

The Centennial Hall (the People's Hall) was entered to the register of monuments of the city of Wroclaw in 1962, and in 1977, it was re-entered under the name of the People's Hall Complex (i.e., Centennial Hall, Four-Dome Pavilion, Restaurant Pavilion, Pergola, the

Corresponding author: Maciej Czarniecki, M.Eng., research field: renovation of architectural monuments (particularly buildings cover with concrete). E-mail: daniel.czerek@op.pl.
Forefront Colonnade and Spire). In 2005, the Polish president declared the building a historical monument, and in 2006, it was listed as a UNESCO (United Nations Educational, Scientific and Cultural Organization) world heritage site, as a pioneering achievement in the engineering and architecture of the 20th century.

The Centennial Hall was renovated just after World War II, later in 1996, but the biggest renovation took place in the years 2009-2011.

\section{Preparation Work}

Prior to starting the renovation of the building, arrangements were made for the acquisition of adequate financial resources, as well as for the drawing up of a number of expert reports and opinions to determine the technical condition of both the building itself and its individual components. The following documents were prepared: conservation documentation regarding window woodwork [1], an expert report on the structure's technical condition [2], expert dendrological reports regarding existing climbers and creepers on the facade and the necessity of securing them during the renovation works, conservation diagnosis and examination of the external wall colors [3], technical opinion regarding the reinforcement of the main tensile ring [4], 
metallographic examinations assessing the condition and characteristics of the components of the steel trusses in the main tensile ring, comprehensive evaluation of the mechanical parameters of the concrete in the main tensile ring [5], documentation of conservation diagnosis and opencast work in the Imperial Hall. The above-mentioned documentation, as well as regular consultations with a group of eminent conservators, art historians and building experts provided the basis for drafting the renovation of the Centennial Hall and obtaining the necessary building permits.

Given the nature of the funding for the project, the repairs were divided into two stages: Stage 1 included repairs to the building's façade; Stage 2-renovation and modernization of the building's interior.

\section{Structural Description}

The Centennial Hall is entirely made of reinforced concrete, with the exception of the main extended ring, which was made as a composite structure of steel trusses embedded in concrete.

The Centennial Hall's structure consists of four interrelated parts in respect of the building's statics:

(1) A lantern of $17.4 \mathrm{~m}$ outer diameter and height of $5.57 \mathrm{~m}$, whose supporting structure consists of four shell-like frames with two-battened poles positioned radially and held by a compression ring at a height of $36 \mathrm{~m}$ above the floor level;

(2) A ribbed dome $23 \mathrm{~m}$ high and spanning $65 \mathrm{~m}$ (Fig. 1) consisting of 32 arched ribs, crowned by a compression ring resting on a main extended ring at

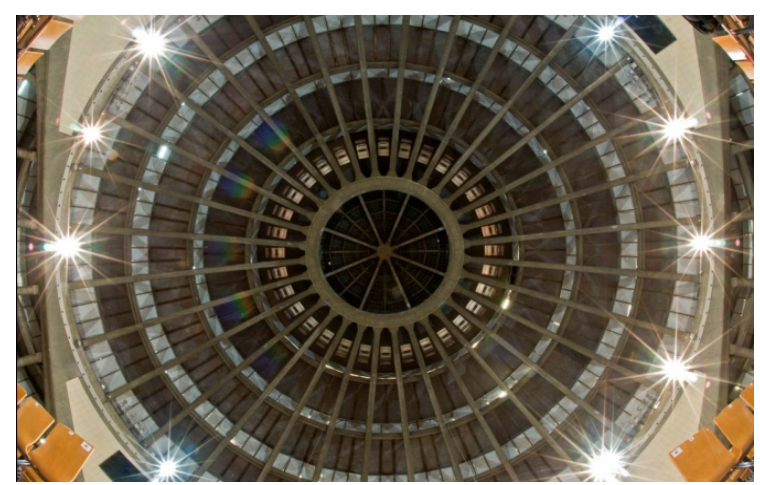

Fig. 1 Ribbed dome of the Centennial Hall. its base. The arches of the dome are held together along their length (reinforced by three intermediate rings), which support the facade walls and the terraced roofs. Under the extended ring, in a bearing channel, along the axis of each arc, there are 32 rocker bearings set, thereby supporting the ribbed dome and separating it from the substructure. The main extended ring along the axis of the bearings has a diameter of $67 \mathrm{~m}$. The bearings are $57 \mathrm{~cm}$ high and are set on the substructure at a height of $18 \mathrm{~m}$ above the auditorium floor level;

(3) The substructure of the dome was solved in an original way. The essential element of the substructure is a cylinder (Fig. 2), $65 \mathrm{~m}$ inner diameter and with a wall of varying thickness (at the foundation approximately $5 \mathrm{~m}$ and at the level of the bearings 2 $\mathrm{m})$. Openings were cut in the walls of the cylinder. At the bottom, four arches were cut, each $41 \mathrm{~m}$ wide at the base and $16.7 \mathrm{~m}$ high. As a result, four arches embedded in massive blocks (pillars of the foundations), remained from the cylinder. The arches of the arcades are double-curved. When burdened by vertical forces from the bearings, they are subject to significant torsional forces. In order to eliminate torsion within the arcs of the arcades, each arcade was supported by six apsidal ribs;

(4) Massive double-angle poise apsidal ribs were based on protruding foundation blocks. The ribs take on all the forces of the trawl, reinforcing the foundations and enlarging the one-dimensional space of the hall from the $65 \mathrm{~m}$ of the cylinder's diameter to a span of $95 \mathrm{~m}$.

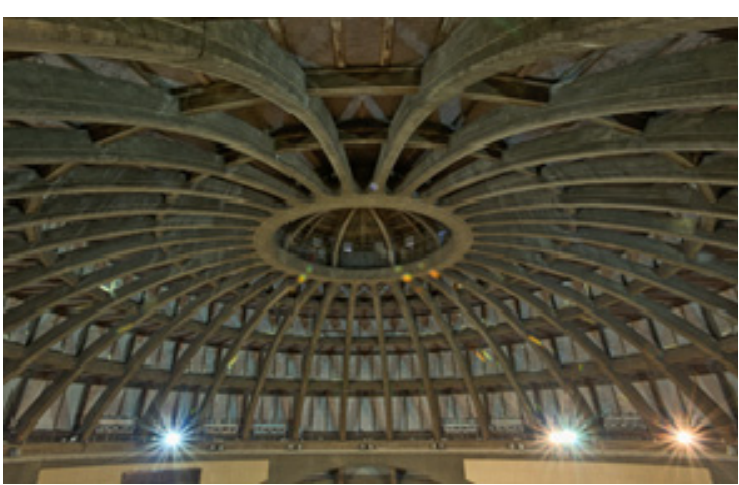


The cylinder of the substructure and the apse is surrounded by one-storey and two-nave lobbies. The lobbies along with the main entrance, the three side entrances and the four oval halls are additionally lit by roof skylights.

\section{Stage 1-Renovation of the Facade}

In February 2009, a permit for building work regarding renovation of the facade, window woodwork and roof covering of the Centennial Hall in Wroclaw was obtained. The general contractor was the Austrian company Alpine Bau $\mathrm{GmbH}$, subcontracting to the Polish companies: Polskie Mosty Sp. z o.o.-facade; PRB (Przedsiębiorstwo Robót Budowlanych) Agad-window woodwork; Profil 77 (formerly Link) Sp. z o.o.- roofing. M.Eng Daniel Czerek managed the project. In March of that year, the renovation started. Greenery growing directly on the walls of the building was secured and cleaning of the surface of the concrete elements of the facade commenced. At the same time, the windows were dismantled for comprehensive renovation in a carpentry workshop and layers of roof covering were removed.

The original facade was made on site using concrete prepared within wooden formwork. On the surface of the facade, one can see within the outline of the formwork a heterogeneous structure resulting from the application of various sizes of aggregates and concrete of varying strength. The facade was badly damaged and dirty. The contamination was caused by the ravages of the weather.

The concrete facade was scratched and cracked in many places. There was multiple damage plus loss caused by the degradation of the concrete. The concrete coating of the reinforcement had lost its protective properties causing the steel to rust, which led to cracking and the loosening of pieces of concrete on the window pillars. The entire surface of the facade required comprehensive conservation and renovation [6].

The following renovation work was done on the concrete surface:

- cleaning of the entire concrete surface of the facade using low-pressure, small-particle abrasive jets (quartz dust) shielded in a water-mist-“Jos's method";

- repairs of losses (re-profiling), crampons and the disruption of corrosion, as well as necessary additions to previously corroded reinforcing bars;

- reconstruction of surfaces in areas of larger losses and disruptions with reference to areas immediately adjacent or surfaces containing similar elements;

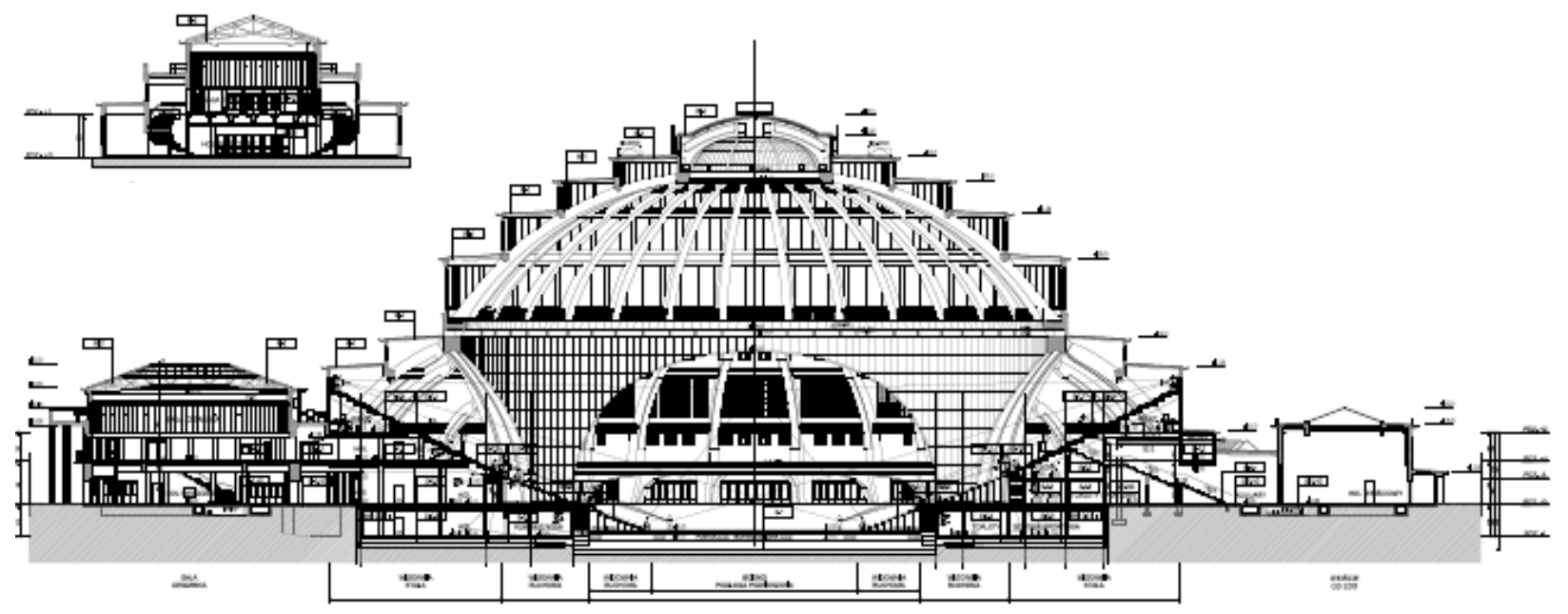

Fig. 2 Technical drawing of the Centennial Hal, cross-section [7]. 
- minor defects and hollowing of the texture of concrete, which did not differ from adjacent areas or locations with other elements of the same kind, at the same time, did not affect the strength of the concrete and were left intact;

- injection of all cracks and scratches to secure the internal structure of the concrete;

- securing the concrete surface of the facade with an impregnating of the required specifications, permeable to water vapor.

Part of the renovation involved securing the main structural element of the Centennial Hall, i.e., the lower extended ring under the ribbed dome, $218 \mathrm{~m}$ long and located at a height of $19.0 \mathrm{~m}$ above ground level. Such securing was justified due to the periodic suspension of sound and lighting equipment from the ribs of the dome, when needed during large events in the hall. The securing of this structural element as proposed by the main contractor, Alpine Bau $\mathrm{GmbH}$, involved girding the extended ring from the outside with 27 non-adherent cables (ø15.50 mm) put together in nine "super-cables" (Fig. 3) made up of three strands each. The cables, located in pipe covers made of PEHD (polyethylene), are arranged on the outer surface of the extended ring of the dome with spacing every $140 \mathrm{~mm}$. Prior to anchoring, the cables were stretched with a force equal to $15 \%$ capacity of the cables, thus ensuring the proper functioning of the anchoring devices. Having been tightened, the cables were injected with a cement grout and secured from the outside with a layer of mineral low-shrink mortar of a texture [8] and color consistent with the requirements of the city conservator and corresponding to the other surfaces on the facade of the Centennial Hall.

Circuit protection of the main structural component of the Centennial Hall with the use of an outer compression system is the biggest reinforcement of this type produced in Poland to date.

It was decided that after cleaning the surface of the facade, paint samples of identical color but different shades would be prepared. In order to determine the appropriate coloring of the external walls, supplementary conservation research was done. The research involved:

- photographic documentation;

- locations of sampling for laboratory tests;

- analysis of the state of preservation of the examined fragments and the impact of destructive factors on the original colors;

- collecting 10 samples;

- specialized laboratory tests;

- analysis of the collected material and test results;

- identification of the colors of the facade walls.

As a result of the research above, it was determined that the earliest layer of paint, ochre-colored, was applied directly onto the concrete's surface. As well as ochre, it contained an unidentified white. Neither an

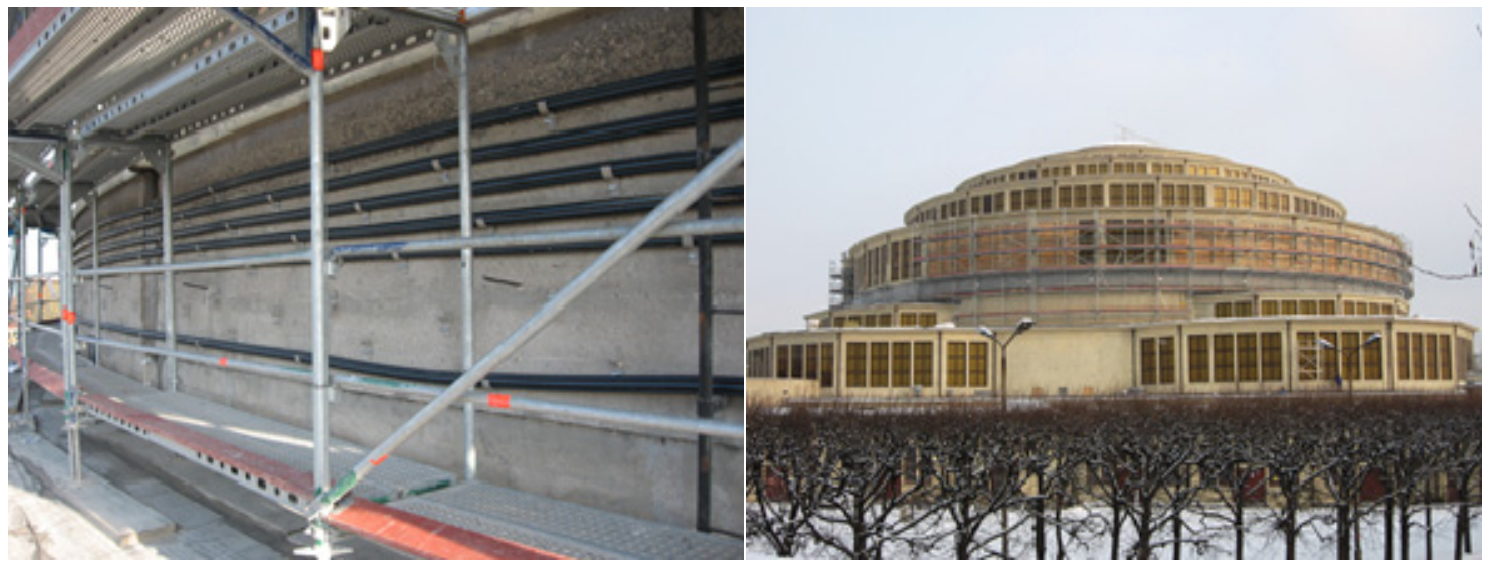

Fig. 3 Reinforcement of the lower extended rim-arrangement of cables and securing of the mortar (photographer: R. Dzugaj). 
organic binder nor any carbonates were detected in the samples. The layers were brittle. Probably, the original binder had disintegrated under the influence of the weather. On the surface of five samples, there were pale yellow layers of over-painting. These had bound well with the ground and some were glossy. An ochre, probably with a silicate binder, had also been used as a pigment.

The general tone of the facade's coloring varied and depended on a number of factors [3]. Weather conditions had an impact on the localized color of the paint layers. Rain had caused pigment leaching and strong sunlight: a "burning" of natural ochre into burnt ochre, salting out and repainting, contributed to a visual effect of color "drizzle" or a mottling. Other causes of this effect were the use of various fillers for the concrete mix (basalts, granites, stones, gravel and sand) and different systems of formworking planks highlighting the individual sections of the facade. Most of the repairs and secondary fillings differed considerably from the original, both in color and technology. They were fugacious and badly preserved.

The original coloring of the facade was hard to identify for the following reasons:

- the dirty surface;

- numerous damages and losses it showed;

- repainting once happened;

- visible numerous repairs to scratches and losses;

- biological damage;

- damage to paint coatings of the windows;

- secondary glazing of all widows.

It was concluded that it was impossible to explicitly determine a single color for the entire surface of the facade. Originally, the paint was applied relatively thinly or translucently. The final choice of color was preceded by several trials made on clean concrete surfaces in order to determine the correct coating. The basic color according to the NCS (natural color system) template is reference numbered: $\mathrm{S}$ 0520-Y20R, or according to KEIM silicate mineral paint KEIM-historisch template: 35 H54 (Farbreihe 35
Goldocker).

Color trial runs were conducted on previously prepared surfaces of the facade. These trials were then assessed by a team of conservators, designers and contractors. As a result of these experiments regarding color, it was decided to use an atypical hue: the color of the preparation and the degree of dilution were determined individually through trial applications.

Materials supplied by KEIM were used for color merging. First, the surface was primed with the KEIM concretal-fixativ preparation, which is a substance with a sol-silicate binder. Next, a glaze coating was made with KEIM concretal-lasur - a sol-silicate paint glaze medium. The glaze coating consists of a mix of four base colors of KEIM concretal-lasur (according to KEIM color palette: 9872, 9008, 9010, 9011) diluted with KEIM concretal-fixativ agent. The color composition thus obtained received the reference number 27/9 HS.

The general reception of the color of the facade is influenced not only by the color of the concrete surfaces, but also by the color of the window woodwork (Fig. 4). In the case of windows, we are dealing with two different materials: wood constituting structure and glass constituting the filling. The color of the paint for the wooden elements of the windows had been determined earlier, during the renovation of the window and door woodwork in the Centennial Hall's corridors. It was then established that it was color No. S 4050-Y80R according to the NCS template.

The examination of the window woodwork, conducted by a team under Tajchman et al. [1] showed that it was made of an extremely resistant exotic wood called ferric mahogany (ironwood). It was recommended that all windows be renovated including replacing damaged stiles and reconstructing the secondary elements. It was established that a wood under the trade name of "Iroko" was the most suitable material for the windows' renovation.

With regard to the window panes, no original 
fragments which could serve as models have survived. There was also no historical documentation describing what type and color of glass were originally used to glaze the windows of the dome. The only trace, which was possible to find, was some documents in the State Archives in Wroclaw containing skimpy notes from 1913-1914 about a delivery of 10 chests with yellow-green opalescent textured glass in May 1913. This is information about Max Berg's approval of the color of the first batch of textured glass No. 21, with the proviso that the color was approved, but the structure of the model No. 23 was the one required. The relief structure of the glass was to improve the acoustics in the building. The color of the glass and its structure were chosen so as to soften sunlight, which could blind the audience.

Further findings showed that the panes for glazing the windows were produced in a glassworks in Pirna, a town near Dresden. An attempt was made to track down original samplers of glass produced at that time in the glassworks. It turned out that the glassworks had closed down and the buildings demolished. No documents of the company survived in the municipal office and there were no exhibits connected with the glassworks in the local museum.

Thanks to the commitment of several people, it was possible to establish the personal data and address of the last manager of the glassworks, who turned out to be a utility glass collector. In his collection, there was a sampler of window glass produced in 1913-1914. There was a sample marked No. 21. It was the type of glass mentioned in the documents in the State Archives in Wroclaw. This is the only sample in color identical to the original color of the panes, but of a slightly different texture pattern.

On the basis of this sample, a search for glass currently produced, and as close to the original as possible, commenced. After assessing more than a dozen window glass samples, the team of conservators, with the designer and contractor participating, decided to use a tempered ornamental glass in ochre.

All renovation work on the facade was done without any restrictions on the use of the building during large events inside the hall and in areas adjacent to it.

\section{Stage 2-Renovation of the Interior}

In January 2011, the renovation of the interior of the building commenced and was finished in August of the same year. This incredibly short period allowed for renovation was a result of external factors, upon which the contractor had no influence. The work of the supervising team was co-ordinated by M.Eng. Maciej Czarniecki, building surveyor, and the entire project was managed by M.Eng. Daniel Czerek of Wroclawskie Przedsiebiorstwo Hala Ludowa Sp. z o.o. Katowickie Przedsiebiorstwo Budownictwa Przemyslowego Budus S.A. undertook this difficult and complex task. The purpose of the renovation was to bring the building up to the requirements necessary for the sports and entertainment facilities, so that this historic building could still serve its original purposes,

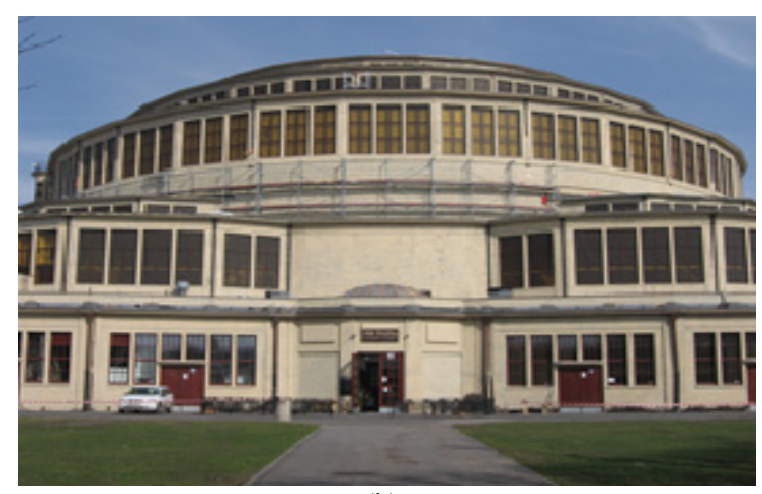

(b)

Fig. 4 After the renovation: (a) front façade; (b) south-west facade. 
i.e., to enable the holding of large events, such as concerts, sports, conferences, artistic performances, trade fairs and exhibitions.

With regard to the architecture, the following works were carried out [7]:

- complete replacement of the auditorium, maximizing spectator numbers and to accommodate events seating 7,000 or standing room for 10,000, and periodically, in the case of sports events seating 10,000 , having lowered the movable floor level by $2.7 \mathrm{~m}$;

- construction of four resting room suites for teams participating in sporting competitions, plus a room for coaches and staff;

- in the lobbies, the closing down of all offices and auxiliary rooms which had been built in the subsequent years of the building's operation;

- enlargement of sanitary facilities proportionate to

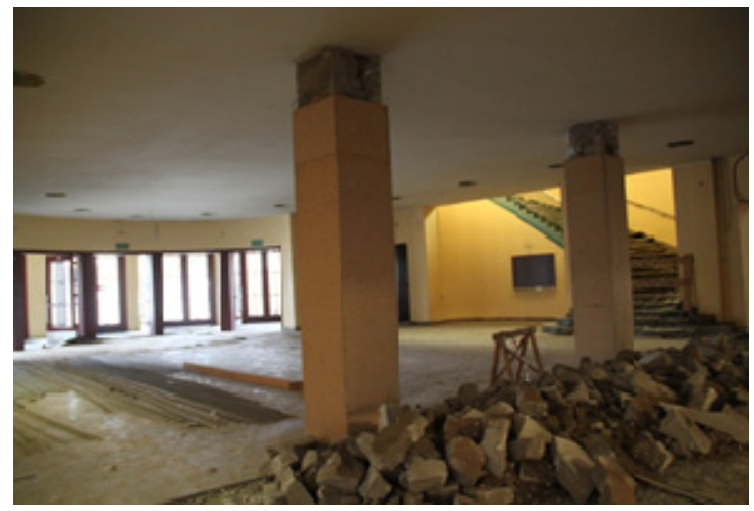

(a) the increased numbers of people expected to be present in the building;

- adjustment of a section of the lobby to the needs of a "cognitive centre" located in the south-west section of the building;

- exchange of the metal window shutters for non-flammable fabric, with fully automated opening and closing;

- replacement of flooring in the lobbies;

- modernization of the Imperial Hall and its "backstage" areas;

- replacement of the acoustic facing in the performance hall;

- removal of the suspended ceiling in the main entrance hall, thereby exposing the original reinforced concrete coffered ceiling (Fig. 5);

- cleaning the internal concrete surfaces using a water stream and detergent, in a closed cycle;

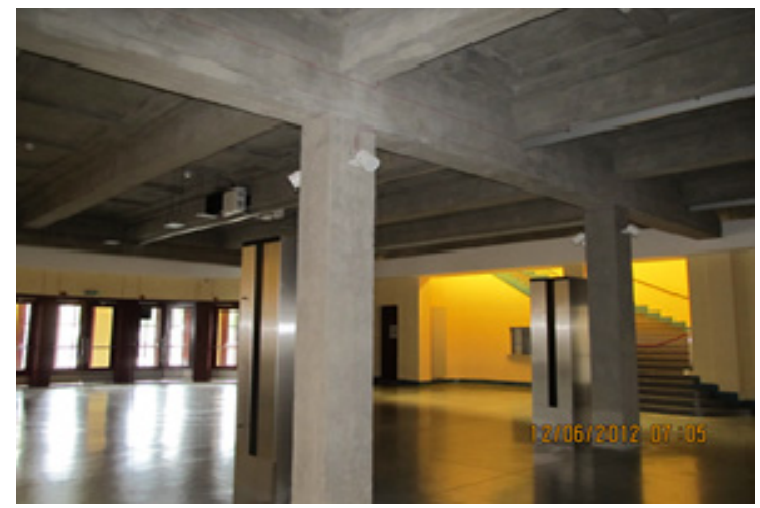

(b)

Fig. 5 Main entrance hall: (a) before; (b) after removal of the suspended ceiling.

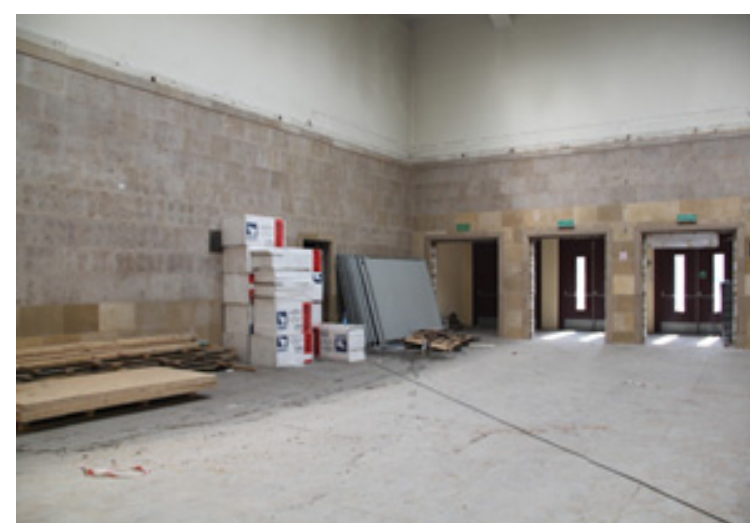

(a)

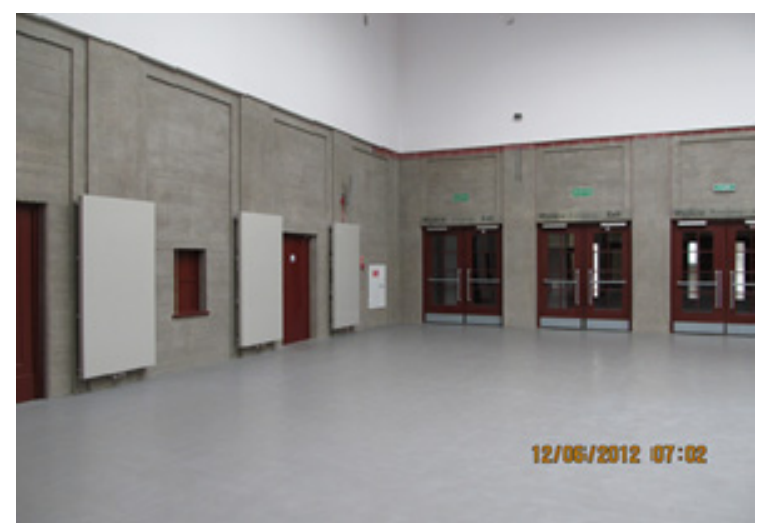

(b)

Fig. 6 Square hall: (a) during and (b) after removal of the stone facing. 
- removal of the secondary stone facings on the walls of the square halls at the south and north entrances, and restoring their original appearance (Fig. 6).

Due to limited funds, the movable-floor mechanisms and grandstands on Level 1 were not done. Therefore, a seating capacity of 10,000 , needed for international sporting events, has not been achieved to date. Nevertheless, the building is technically prepared for the installation of these fittings.

With regard to actual construction, the following work was done:

- demolition of reinforced concrete grandstands and flooring (installed in 1996) within the performance hall;

- lowering the flooring of the performance hall by $3.70 \mathrm{~m}$ (Fig. 7a) to enable the installation of the movable floor $[9,10]$;

- securing and reinforcing the dome's lantern using a carbon fibre tape (Fig. 7b);

- construction of new reinforced concrete structure of the fixed grandstand and the telescopic steel grandstands;

- repair of the reinforced concrete construction elements inside the hall (re-profiling);

- installation of new conduits under the floor for plumbing and heating installations.

In terms of installations, all existing plumbing,

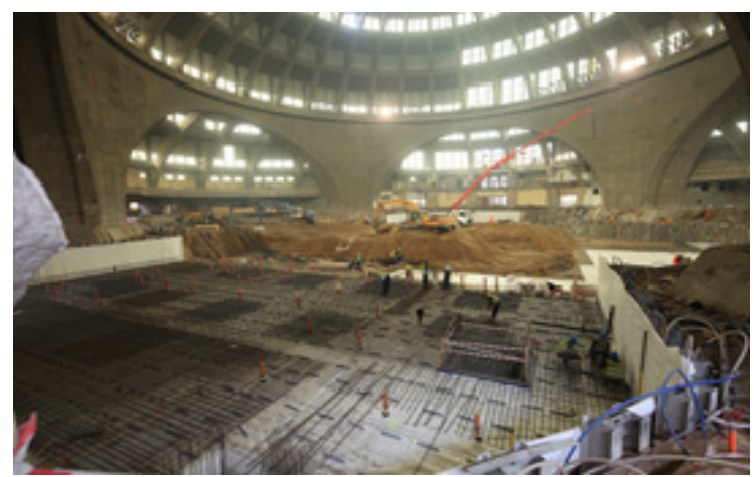

(a) electrical, heating, ventilation, sound, fire alarm, fire protection, information and surveillance systems were entirely replaced.

Following consultation with the conservation authorities, the following guidelines were established and followed:

- decor from 1913 was the guiding model for the permanent interior design (Fig. 8);

- because of the acoustics, facings made utilizing the latest technology were used on the pillars of the arcades, instead of "suprema" (Heraclitus);

- fans in the arcade pillars were replaced with more efficient ones;

- all historical staircases and banisters were preserved;

- the suspended ceiling in the main entrance was removed;

- stone facings in the square halls were removed, thereby exposing the natural surface of the reinforced concrete;

- demolition of the existing grandstands with their substructure to the floor level, was permitted, except for the balconies made in 1913;

- plywood seats and elements of interior decoration based on original materials were installed on the new grandstands;

- the acoustic warning system's components remain visible, but in a manner that barely competes with the interior arrangements of the historical building.

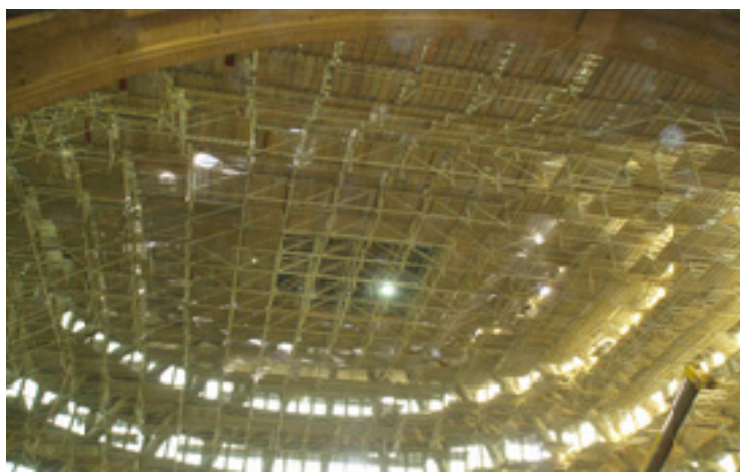

(b)

Fig. 7 Renovation of the interior: (a) lowering the flooring in the performance hall; (b) the scaffolding suspended from the dome. 


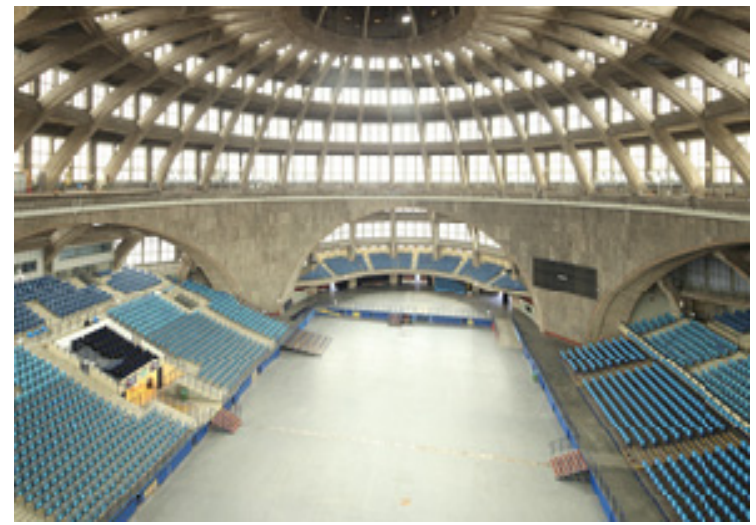

(a)

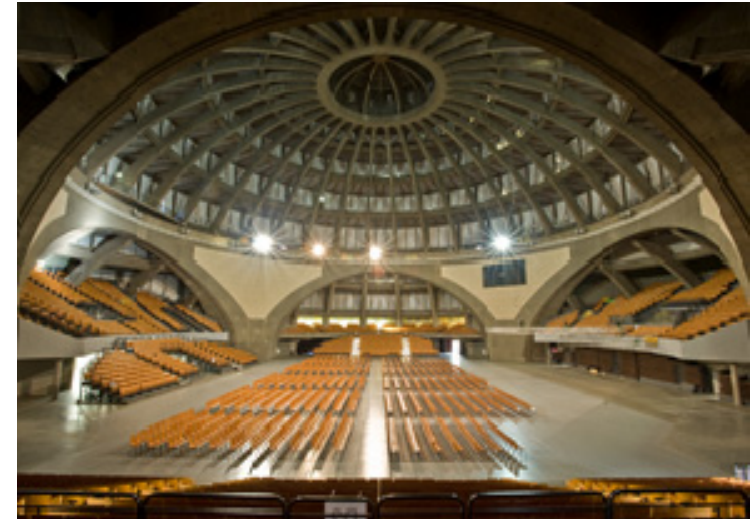

(b)

Fig. 8 Auditorium: (a) before; (b) after the renovation (photographer: M. Golen).

In a separate part of the lobbies, a "cognitive centre" equipped with the latest audio-visual technology was opened. In this "cognitive centre", a multimedia, educational exhibition presenting the history of the Centennial Hall and the adjacent areas was constructed. Visitors to the hall can both see the existing building and travel back in time to see the changes to which it was subjected.

\section{Conclusions}

All the activities mentioned above aimed to bring the building into a good technical condition and adjust it to the requirements applicable to contemporary public buildings. The basic premise was to preserve the authenticity of the original building materials by utilizing repair technologies that maintain the historic character of this building. Conservation recommendations and the historical background of the hall, including the unique concept of Max Berg, were most carefully taken into consideration. In this way, a historic building of unique qualities can still be extensively used and pulsate with life. It can now serve the purpose for which it was designed and built.

On June 21, 2012, the building received a special award in competition for the best architectural project: "Beautiful Wroclaw 2011".

Prior to start the design and building work, detailed historical-conservation-architectural research of the individual buildings and adjacent areas was conducted. A historical study, color tests, architectural inventory and technical expertise were commissioned.

Within Wroclawskie Przedsiebiorstwo Hala Ludowa Sp. z .o.o., a historical-conservation team was appointed. Its responsibility was to advise and supervise the renovation of the Centennial Hall and other buildings located in the area. Global specialists in the protection and conservation of monuments were consulted regarding the activities connected with the revitalization of the Centennial Hall Complex.

Only compliance with the detailed and rigorous procedures used during the renovation of the building, would we guarantee the desired result, i.e., the revitalization of the Centennial Hall. This result was achieved thanks to the multilateral cooperation and remarkable commitment of a large group of people from various professions.

The participants of the international conference "Concrete - Challenges of Conservation" organized in Wroclaw on 23rd and 24th October 2009 referred with appreciation to the renovation work carried out on the facade of the Centennial Hall.

The group was efficiently organized by Hana Cervinkowa, president of the Board of Wroclawskie Przedsiebiorstwo Hala Ludowa Sp. $\mathrm{z}$ o.o. in 2006-2011. Thanks to her dynamism, two key projects co-financed with European Union funds were completed: the renovation and extension of the Restaurant Pavilion and a major renovation of the Centennial Hall. 


\section{References}

[1] Tajchman, J., Schaaf, U., and Bożejewicz, E. 2008. Conservation Documentation Regarding Window Woodwork of Centennial Hall. Wroclaw: Wrocławskie Przedsiębiorstwo Hala Ludowa Sp. z o.o.

[2] Persona, M., and Runkiewicz, L. 2009. Expert Report on the Structure's Technical Condition of Building Centennial Hall. Wroclaw: Wrocławskie Przedsiębiorstwo Hala Ludowa Sp. z o.o.

[3] Wójtowicz, R. 2009. Conservation Diagnosis and Examination of the External Wall Colours of the Centennail Hall. Wroclaw: Wrocławskie Przedsiębiorstwo Hala Ludowa Sp. z o.o.

[4] Lagoda, M. 2009. "Technical Opinion Regarding the Reinforcement of the Main Tensile Ring." Expertise thesis, Road and Bridge Research Institute, Wroclaw University of Technology.

[5] Moczko, A. 2010. "Complex Evaluation of Mechanical Parameters of Concrete under the Dome of the Main Ring of the Centennial Hall." Expertise thesis, Construction
Institute, Wroclaw University of Technology.

[6] Konarzewski, L., and Persona, M. 2009. Design of Building Facade Renovation of the Centennial Hall. Wroclaw: Wrocławskie Przedsiębiorstwo Hala Ludowa Sp. z o.o.

[7] Tomaszewski, L. 2010. Restoration of the Centennial Hall in Wroclaw, Chapman Taylor International Services. Wroclaw: Wrocławskie Przedsiębiorstwo Hala Ludowa Sp. z o.o.

[8] Sosnal, R., and Krążelewski, J. 2009. Temporary Security Trench Using Palisadę of Columns DSM and Soilcrate (Jet Grouding)-Specialized Technique of Foundation. Wroclaw: Wrocławskie Przedsiębiorstwo Hala Ludowa Sp. z o.o.

[9] Puła, O. 2009. Technical Opinion Concerning the Deep Excavation inside Centennial Hall. Wroclaw: Wrocławskie Przedsiębiorstwo Hala Ludowa Sp. z o.o.

[10] Prabucki, P., Onysyk, J., Biliszczuk, J., and Madryas, C. 2010. Concept of Strengthening the Main Ring of the Dome in Centennial Hall. Wroclaw: Wrocławskie Przedsiębiorstwo Hala Ludowa Sp. z o.o. 